\title{
A comparative study of the physical development and motor performance of mentally non-handicapped children and children with intellectual and development disabilities
}

\author{
E Szabó ${ }^{1}$, N Erdei $^{2}$, Sz Bene $^{3}$ \\ ${ }^{1}$ University of Kaposvár, Kaposvár, Hungary \\ University of Physical Education Doctoral School, Budapest, Hungary \\ ${ }^{2}$ Móra Ferenc Primary School, Budapest, Hungary \\ University of Debrecen, Ihrig Károly Doctoral School in Business Economics and Organizational Studies, \\ Debrecen, Hungary \\ ${ }^{3}$ University of Pannonia, Keszthely, Hungary
}

Received: November 9, 2014

Accepted after revision: June 4, 2015

\begin{abstract}
Several studies state that there might be a difference in the physical development and the motor performance of the mentally non-handicapped children and those with intellectual and development disabilities. The aim of our research was to compare the two groups from these aspects. The study included the assessment of the physical development and motor performance of altogether 225 primary school pupils (mentally non-handicapped and with intellectual and development disabilities) aged 8-11. The following indicators of physical development and build were examined: body height, body weight and body mass index (BMI), musculoskeletal plasticity index, biceps and triceps skinfold thickness. The motor tests included: $20 \mathrm{~m}$ dash, standing long jump, medicine-ball throwing, six minutes continuous running, obstacle race-test and a match test. We also examined the children's chronological (decimal) and morphological age. Data were analysed with SPSS programme. The differences between the averages were calculated with ANOVA and Fisher's LSD tests. The results show that the children with intellectual and development disabilities are in general less developed physically than non-handicapped children of the same age and sex. It is also concluded that in most motor tests the children with intellectual and development disabilities fall behind the non-handicapped ones.
\end{abstract}

Keywords: primary school pupils, non-handicapped children, children with intellectual and development disabilities, physical development, motor performances

\section{Introduction}

Body height and the body weight are the most often used elements to define physical development. Conditional abilities can be best recognised and followed in the development of the speed of movement and locomotion, which normally go together with the maturation of the nervous system and the endurance, which is proportional to the body weight $(6,18$, 21). During the motor tests, the principle is that we only can get a thorough knowledge of the human motor system if we measure the conditional and the co-ordination skills together (7).

Corresponding author: Eszter Szabó

University of Kaposvár

Guba Sándor u. 40, H-7400 Kaposvár, Hungary

Phone: +36-30-506-7978; E-mail: szabo.eszter@ke.hu 
Tóth (16) concluded that the conditional skills clusters of children stay invariable at the age of 10-11. It is the morphological development of the body that plays a major role in the formation of skills clusters. Sziva et al. (14) obtained the results result of the tests of boys aged 7-11 years showed that in the past 25 years, their physical conditions have deteriorated and the health risks have grown. According to Mészáros et al. (9) there was no difference between the average body heights of the two groups, but it went soaring with the age of those in the special PE class, who weighed less. In general, the boys in the PE classes produced better physical performances. Suchomel (13) did not find difference of body height between the groups of the same age, the same sex and the different motor performance. However, the body weight, the body mass index and the amount of under-skin fat was higher in the case of the children with weaker motor performances. In the case of those who produced better sports results, the somatic parameters (body weight, body mass index, under-skin fat) showed a closer correlation with the motor performance. Based on the study of Szmodis et al. (15) there was a significant difference between the same age (14- and 16-year-old) groups of girls and boys in body height and body weight. As for body mass index the mean values of boys aged 7-13 significantly differed from their peers; as for girls, the age group averages did differ significantly. The triceps skinfold thickness of girls was higher than that of the boys as early as at the age of 7-10 years. The musculoskeletal plasticity index's age average was significant in the case of 10-15 years old boys and 10-11 year old girls.

As for the children with intellectual and development disabilities the Eurofit testing system (3) was used. The cross-sectional examinations let us conclude that the averages of the body measurements of the children with intellectual and development disabilities differ from the averages of the non-handicapped children, but statistically, the differences are hardly ever significant. The differences grow with the age, the body build often becomes disproportional and the differences mentioned above have a different indication $(2,17)$. According to Ozbic and Filipcic (10), based on the children's movement coordination and motor performance, it is easy for primary school teachers to identify the children with learning difficulties. Pilák (11) used the Hungarofit system to compare the motor performances of primary school pupils going to majority schools with those of the children with slight intellectual and development disabilities. It was found that in all the tests, they performed worse than the non-handicapped children. The hypothesis of the author was not confirmed, namely that the children with intellectual and development disabilities perform worse only in the tests demanding physical power and not in the ones demanding endurance and speed.

Vámos (19) with reference to the studies carried out by Laborfalusi states that $40 \%$ of the children with intellectual and development disabilities have slightly weaker, less developed builds, lower than average body height, and body weight. Furthermore, it can be stated that there is a visible tonicity or hypotonia (too tense or too flaccid muscles) as well as gross motor skills problems. Disturbances of bearing and the weakness of fine movement coordination.

Vámos (19) and Leibinger (8) also states that regarding their motor skills, the $1^{\text {st }}$ and $2^{\text {nd }}$ grade children studying in classes with adapted curriculums fall behind those who study in normal curriculum classes. According to Broadhead and Church (1) the 'Physical Dexterity' test is more reliable to identify children with intellectual and development disabilities than the 'Motor Proficiency' test. There were several methods developed to test people's motor proficiency, which are at the same time suitable to show the possible deficiencies as well Rio et al. (12). 
Considering the research results in the field outlined, we may state that there are several publications about the physical development and the motor proficiency of non-handicapped children. However, there are a smaller number of studies that examine the children with intellectual and development disabilities. There are few exact comparisons made between the two groups. It also makes comparison based on the results of former studies more difficult that the tests were made neither under the same conditions nor with the same method.

Taking into consideration the scarcity of aforementioned data, it was our studies' aim to carry out comparative analyses between groups of non-handicapped children and children with intellectual and development disabilities of the same age and the same sex to assess the correlation between their physical development and motor proficiency. We also examined whether the children with intellectual and development disabilities fell behind the nonhandicapped ones in their physical development and whether they performed significantly worse in the motor skills. These data can be used to help the diagnosis and the therapy of children with intellectual and development disabilities.

\section{Materials and Methods}

The tests were carried out in the town of Keszthely in Hungary between 2009 and 2013, where there was opportunity to compare body measurements and motor proficiencies of primary school pupils, both non-handicapped children and children with intellectual and development disabilities. The pupils in the survey were aged 8-11, there were 225 of them altogether, 160 non-handicapped and 65 with intellectual and development disabilities. The number and distribution of the children in the survey is contained in Table I.

Table I. Introduction of test samples (number of children)

\begin{tabular}{|c|c|c|c|c|c|}
\hline \multirow[t]{2}{*}{ Age (year) } & \multicolumn{4}{|c|}{ Number } & \multirow[t]{2}{*}{ Total } \\
\hline & NHB & BIDD & NHG & GIDD & \\
\hline 8 & 21 & 8 & 13 & 5 & 47 \\
\hline 9 & 20 & 9 & 22 & 0 & 51 \\
\hline 10 & 18 & 13 & 31 & 6 & 68 \\
\hline 11 & 13 & 14 & 22 & 10 & 59 \\
\hline Total & 72 & 44 & 88 & 21 & 225 \\
\hline
\end{tabular}

\footnotetext{
Abbreviations: NHB: non-handicapped boys,

BIDD: boys with intellectual and development disabilities,

NHG: non-handicapped girls,

GIDD: girls with intellectual and development disabilities
}

We examined the following physical parameters: body height, body weight, triceps- and biceps skinfold thickness. From among the build indicators we used the Quetelet-index (body mass index, abbreviated as: BMI (4), which is a statistical indicator comparing the body height and the body weight of the individual. It is calculated by dividing the body weight given in kilograms by the body height (given in meters) squared (5), and the musculoskeletal plasticity index, which is an indicator expressed by the three measurements that characterize the bone and the muscle system (shoulder breadth, lower arm perimeter, hand perimeter) added up and expressed in centimeters. The age of the children: the decimal age, the 
conventional age indicator used in everyday life, that is the chronological age of the children, the time between the birth and the time when the survey is made. In scientific studies, the chronological age is often expressed in a decimal system, it is expressed with an 0.01 year precision while the morphological age is based on the physical measurements. To define it, the following variables are necessary: the decimal value of the chronological age, the body height, the body weight, and the musculoskeletal plasticity.

The motor tests were the following: $20 \mathrm{~m}$ dash, standing long jump, throwing a medicineball forward, six minutes' continuous running, obstacle race-test and a fine motor skills, hand-speed and hand synchronization test: the match test.

These tests were carried out in the classrooms (match test and measurements) and at the school's sport ground or in the gym (gross motor skills), with previous permission of the parents, who had also been informed about these tests in accordance with the prescriptions of the Helsinki Declaration (20).

The data obtained were entered into Microsoft Excel tables and given a basic SPSS program statistical analysis. We calculated the average, the standard deviation, the standard error, minimum and maximum values and the variance coefficient. The differences between the averages were calculated with ANOVA and Fisher's LSD tests.

\section{Results}

Table II shows the real chronological (decimal) age of the children and the morphological age of the children, which makes the decimal age, body height, body weight and musculoskeletal plasticity index necessary. It can be seen that the morphological age of both the boys and the girls with intellectual and development disabilities is lower than that of the non-handicapped children.

Table II. Average and standard deviation of the children's decimal age and morphological age and the difference of averages of the children of the same age and sex

\begin{tabular}{|c|c|c|c|c|c|c|c|c|c|}
\hline \multirow[t]{2}{*}{ Age (year) } & & \multicolumn{4}{|c|}{ Decimal age } & \multicolumn{4}{|c|}{ Morphological age } \\
\hline & & NHB & BIDD & NHG & GIDD & NHB & BIDD & NHG & GIDD \\
\hline \multirow{3}{*}{$\begin{array}{l}8 \\
(7.51-8.50)\end{array}$} & Mean & 7.97 & 7.98 & 7.97 & 8.04 & 8.64 & 8.30 & 8.43 & 7.20 \\
\hline & SD & 0.28 & 0.34 & 0.30 & 0.35 & 1.02 & 1.74 & 1.11 & 1.02 \\
\hline & Sig. & & & & & & & & \\
\hline \multirow{3}{*}{$\begin{array}{l}9 \\
(8.51-9.50)\end{array}$} & Mean & 8.96 & 9.01 & 9.04 & & 9.62 & 8.22 & 10.17 & \\
\hline & SD & 0.27 & 0.32 & 0.26 & & 0.82 & 0.63 & 0.90 & \\
\hline & Sig. & & & & & $* * *$ & $* * *$ & & \\
\hline \multirow{3}{*}{$\begin{array}{l}10 \\
(9.51-10.50)\end{array}$} & Mean & 10.03 & 10.03 & 10.00 & 9.93 & 10.37 & 9.45 & 10.68 & 10.05 \\
\hline & SD & 0.34 & 0.22 & 0.30 & 0.29 & 0.99 & 1.74 & 1.31 & 0.80 \\
\hline & Sig. & & & & & & & & \\
\hline \multirow{3}{*}{$\begin{array}{l}11 \\
(10.51- \\
11.50)\end{array}$} & Mean & 10.82 & 11.00 & 10.83 & 11.03 & 11.33 & 10.28 & 11.15 & 10.58 \\
\hline & SD & 0.20 & 0.34 & 0.21 & 0.25 & 1.21 & 1.28 & 0.85 & 1.70 \\
\hline & Sig. & & & $*$ & $*$ & $*$ & $*$ & & \\
\hline
\end{tabular}

Abbreviations and symbols: NHB: non-handicapped boys,

BIDD: boys with intellectual and development disabilities, NHG: non-handicapped girls,

GIDD: girls with intellectual and development disabilities, $\mathrm{SD}=$ standard deviation,

Sig. $=$ significant differences, $* p<0.05, * * * p<0.001$ 
In many cases, the 8-year-old girls and boys with intellectual and development disabilities aged 9,10 and 11 years fell - up to one year - behind the non-handicapped children of the same decimal age. However, there is a significant difference between only the boys aged 9 and 11. It has to be noted, that there was a morphological age at which the nonhandicapped children outpaced their real age. It occurred with boys aged 8 and 9 and girls aged 9 and 10 .

Table III shows the children's body height, body weight and body mass index. As for their body height the children with intellectual and development disabilities were always shorter than the non-handicapped children of the same age and sex. However, there was a significant difference between only the 8 -year-old girls and the 9 -year-old boys. It also has to be noted that it also occurred that girls of the same age going to the same school were taller than the boys. The 9-, 10- and 11-year-old non-handicapped girls were taller than the nonhandicapped boys as well as the 10- and 11-year-old girls with intellectual and development disabilities on average were taller than the boys with intellectual and development disabilities of the same age. However, the girls with intellectual and development disabilities were never taller than the non-handicapped boys.

As for body weight, the situation is the same. In almost every case, except for the 11-year-old girls, the non-handicapped children are heavier than the children with intellectual and development disabilities of the same age and the same sex; though the difference is very small.

Only in the case of the 9- and the 11-year-old boys the difference is significant. The 9-year-old non-handicapped girls are a bit heavier than the non-handicapped boys as well as the 11-year-old girls with intellectual and development disabilities are heavier than the boys with intellectual and development disabilities of the same age. However, the girls with intellectual and development disabilities are never heavier than the non-handicapped boys. The age differences can well be seen in the case of the groups of the same school group and the same sex. (It is only the 9-year-old boys who weigh less than the 8-year-olds.)

As for the body mass index, the age differences do not show so clearly. In the case of boys, in both school types, the body mass index of 8-year-olds was higher. In the case of nonhandicapped girls, the 10-year-olds had a higher value than the 11-year-olds. In the case of non-handicapped girls the 10-year-olds had a higher value than the 11-year-olds. In the case of boys, with the boys of the same age the non-handicapped boys always had a higher value although only the 11-year-olds showed a significant difference, while in the case of girls, the girls with intellectual and development disabilities always had a higher value than the nonhandicapped girls. The non-handicapped 9-year-old girls had a higher body mass index than the non-handicapped boys, while the 10- and 11-year-old girls with intellectual and development disabilities had a higher body mass index than the boys with intellectual and development disabilities. The girls with intellectual and development disabilities never, not even in one case had a higher body-weight index than the non-handicapped boys.

Table IV shows the difference between the averages of the musculoskeletal plasticity index, the biceps- or triceps skinfold thickness, their deviation and the difference between the body measurements of the children of the same age, the same sex but of different intellectual capacity.

The musculoskeletal plasticity index is the sum of the shoulder breadth, perimeters of the lower arm and the hand. It shows the development of the bone and the muscle system. Here there were significant differences in more cases than with the body height, body weight or the body mass index. Apart from the 8-year-olds, at all age groups, in every case, the non- 
handicapped children had significantly higher musculoskeletal plasticity index than the other children did. It was also higher with the 8-year-olds but not significantly. It is interesting to note, that the non-handicapped 8-year-old girls' musculoskeletal plasticity index is higher than that of the 8-year-old non-handicapped boys. Also, the musculoskeletal plasticity index of the 10- and 11-year-old girls with intellectual and development disabilities was higher than that of the boys on the same level. Here also in every case, the musculoskeletal plasticity index of the girls with intellectual and development disabilities was lower than that of the non-handicapped boys.

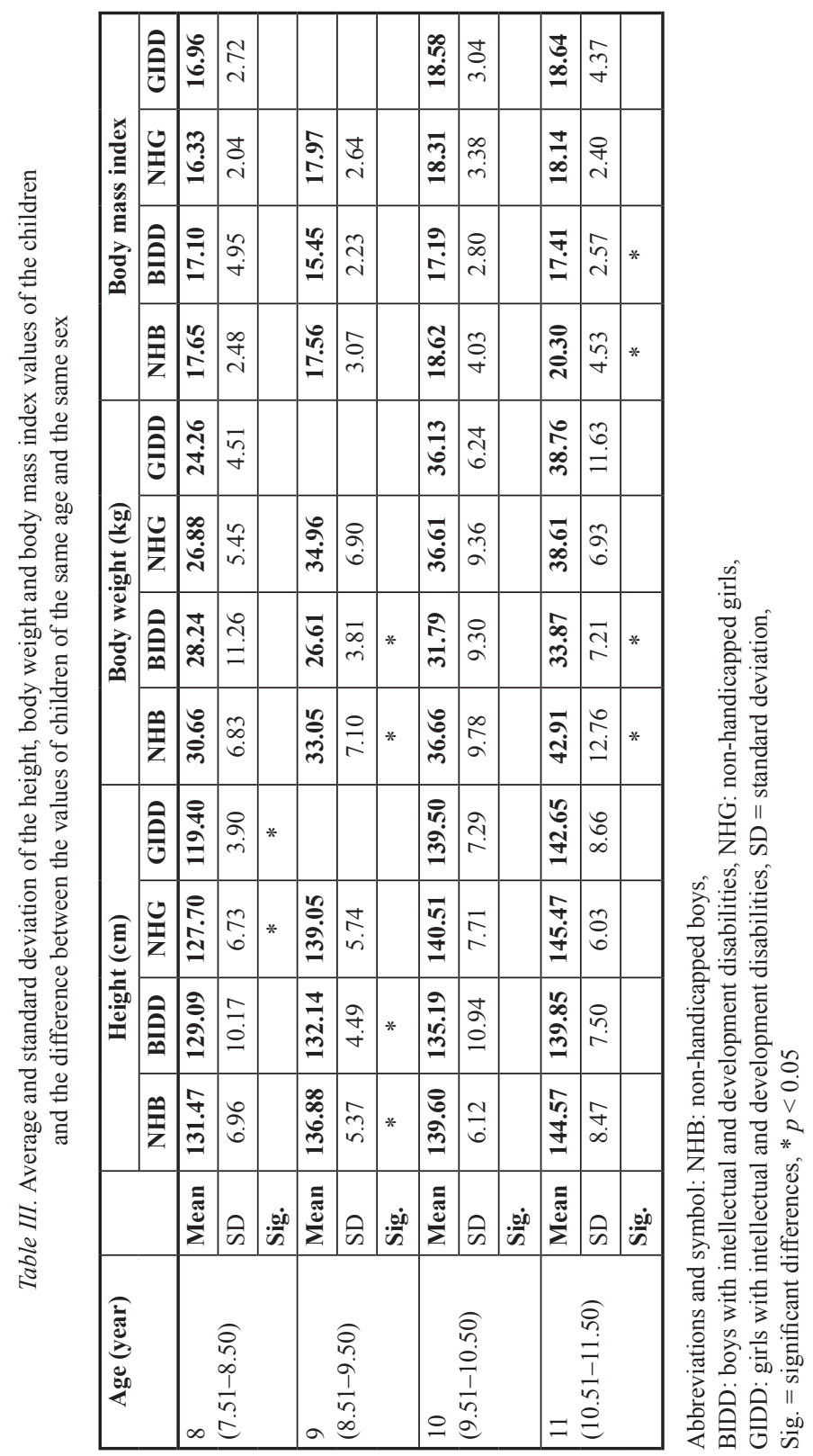




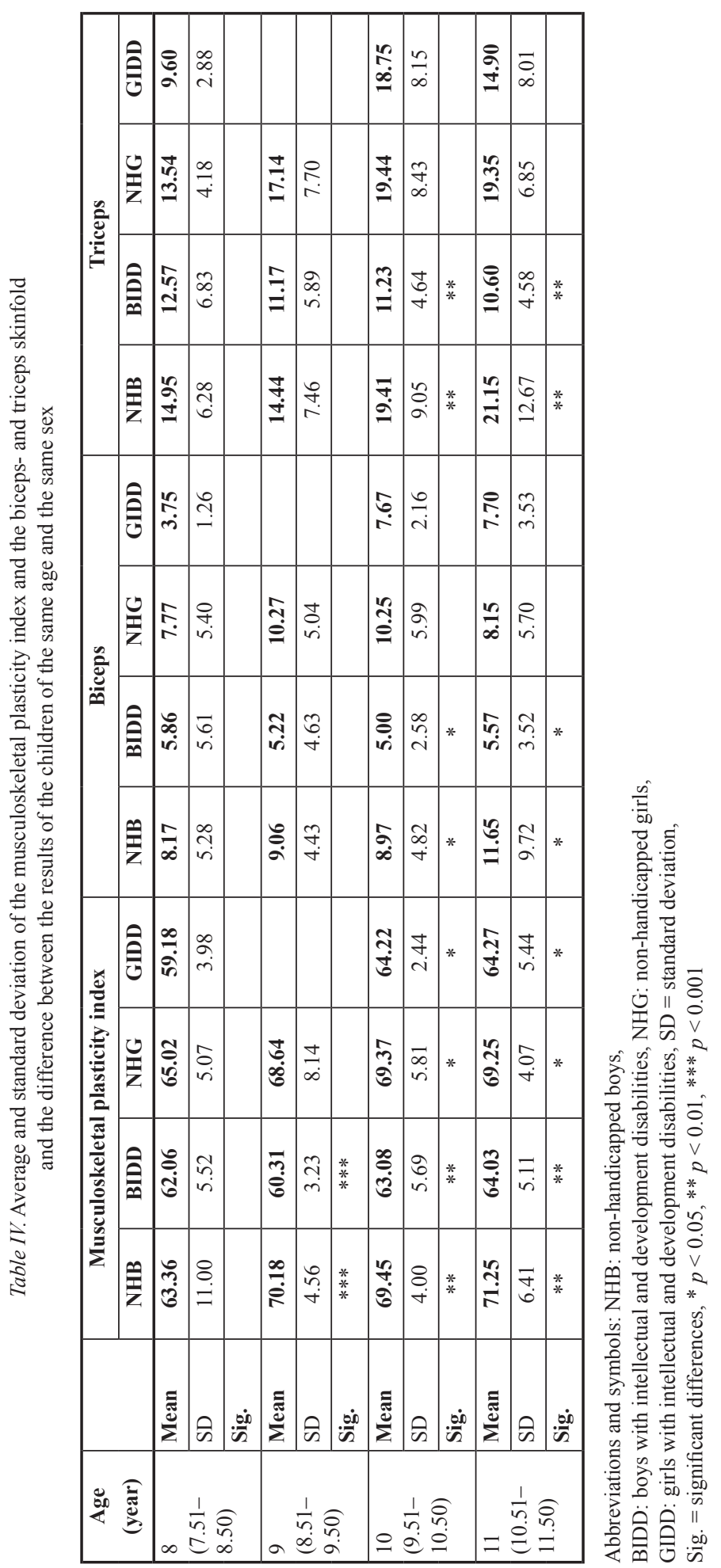




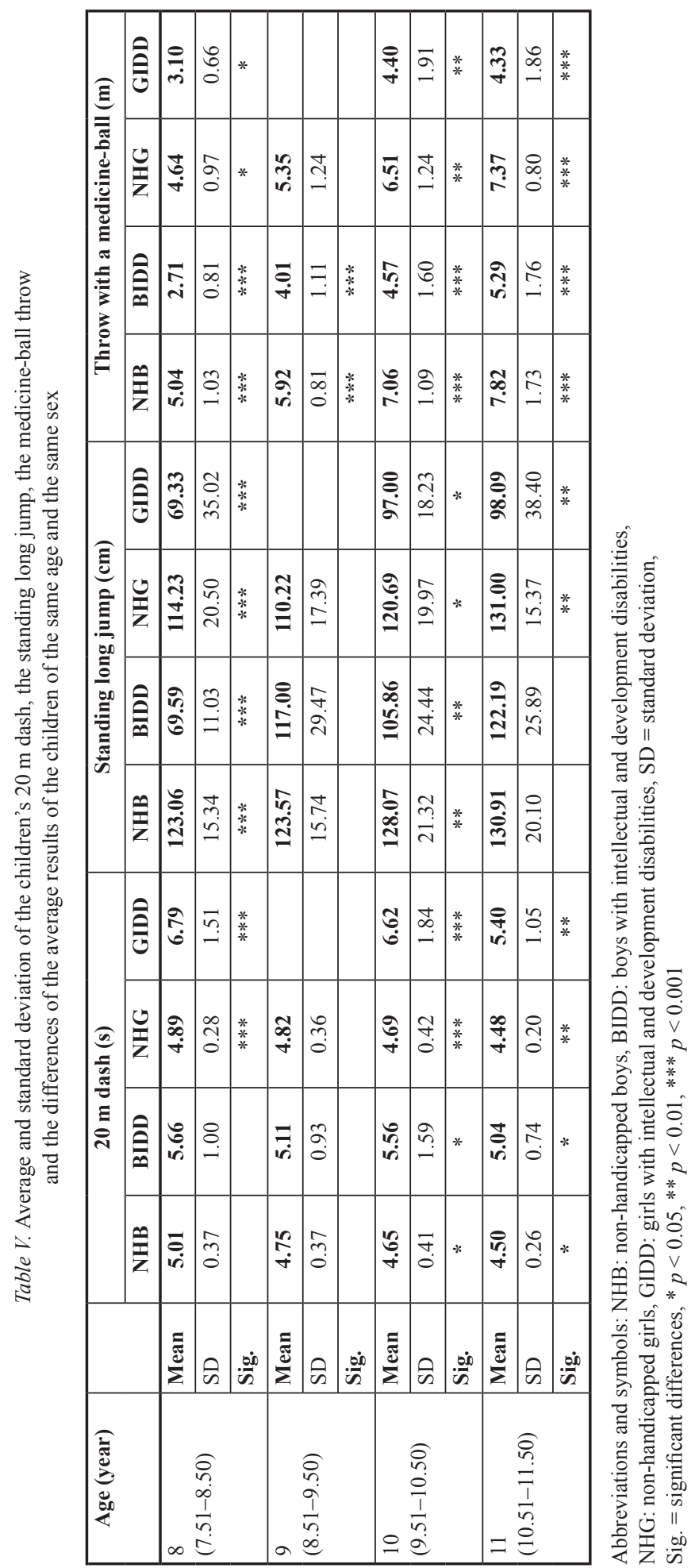


There were fewer significant differences when the biceps- and the triceps skinfold thickness was measured. They occurred in the same cases, namely between the 10- and 11year-old non-handicapped boys and girls with intellectual and development disabilities.

The non-handicapped children always had a higher average of the skinfold thickness, even the non-handicapped girls had higher averages than the boys with intellectual and development disabilities.

Among the non-handicapped ones, the 9- and 10-year-old girls had a thicker skinfold than the boys, while the 8 - and the 11-year-olds had a thinner skinfold than the boys. When the children with intellectual and development disabilities were 8 years old, the boys had thicker skinfolds, but then at the age of 10 and 11, it was the girls who had thicker skinfolds.

Table V shows the results of some motor tests. In the $20 \mathrm{~m}$ dash speed test the children with intellectual and development disabilities performed worse at every age than the nonhandicapped children of the same age and the same sex.

There is a significant difference between the 8-year-old girls as well as the boys and girls aged 10 and 11. Among the non-handicapped 8- and 11-year-olds, the girls reached better results. At all ages, the non-handicapped girls always reached better results than the boys with intellectual and development disabilities.

So did the boys with intellectual and development disabilities compared with the girls with intellectual and development disabilities.

In standing long jump, the non-handicapped children always did better than the children with intellectual and development disabilities.

The differences were significant in the case of the 8- and 10-year-old boys and girls, as well as, the 11-year-old girls. The boys always did better. Except for the 9-year-old girls, the non-handicapped girls always did better than the boys with intellectual and development disabilities in the other age groups.

In the medicine-ball throw, (a speed-power test) at all age groups, the non-handicapped children significantly outdid their contemporaries with intellectual and development disabilities.

Except for the 8-year-old girls with intellectual and development disabilities in all other age groups, the non-handicapped boys outdid the non-handicapped girls, while the boys with intellectual and development disabilities outdid the girls with intellectual and development disabilities. Also, the non-handicapped girls in all cases outdid the boys with intellectual and development disabilities.

Table VI shows the results of the 6 minutes' continuous running, the obstacle race and the match test. In the 6 minutes' continuous running except for the 11 -year-old boys, in all the cases examined, we found that the non-handicapped children significantly outdid the children with intellectual and development disabilities. It has to be noted, that the 11-year-old non handicapped boys ran more than the boys with intellectual and development disabilities, but the differences were not significant. The non-handicapped boys ran more than the boys with intellectual and development disabilities while the non-handicapped girls outdid the girls with intellectual and development disabilities. In this test, in every case, the non-handicapped girls outdid the boys with intellectual and development disabilities.

In the obstacle race, in every case, the non-handicapped children did significantly better than their contemporaries. Both among the non-handicapped children and the children with intellectual and development disabilities it was the boys who complete the race the fastest and the non-handicapped girls outdid the boys with intellectual and development disabilities. 


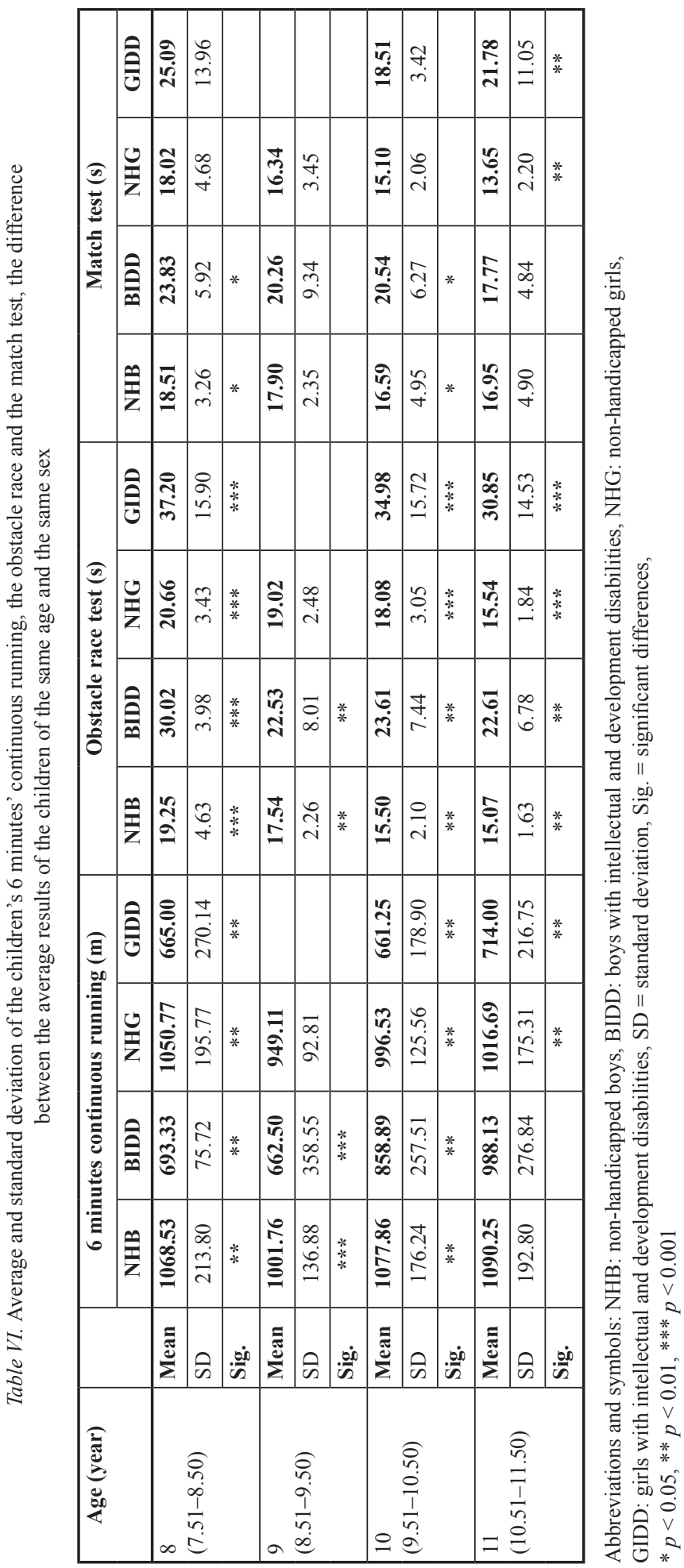


In the categories, the improvement with age can be well seen except for the boys with intellectual and development disabilities who did not show any improvement between 9 and 10 years of age.

In the match test (a fine motor skills test in which the synchronized hand movement and speed are important) it was also the non-handicapped children who did better but only the 8- and 10-year-old boys and the 11-year-old girls showed a significant difference. The nonhandicapped girls were faster than either the non-handicapped boys or the boys with intellectual and development disabilities. In the case of the children with intellectual and development disabilities only the 9-year-old girls were faster than the boys. So, in this test, the non-handicapped girls gave the best and the girls with intellectual and development disabilities gave the worst performance.

\section{Discussion}

The results of our investigations show that the children with intellectual and development disabilities fall behind the non-handicapped children in their physical development. We got significant differences between the non-handicapped children and the children with intellectual and development disabilities of the same sex in their morphological age, in the case of the 9- and the 11-year-olds; in the body height in the case of the 8-year-old girls and the 9-year-old boys; in the body weight in the case of the 9-year-old and the 11-year-old boys; in the body mass index values in the case of the 11-year-old boys, in the musculoskeletal plasticity index in the case of the 9-year-old boys, as well as the 10- and the 11-year-old boys and girls; in the biceps-and triceps skinfold thickness in the case of the 10- and the 11-yearold boys. What we found corresponds to the results published by Buday and Kaposi (2), as well as Tóth (17), who similarly to us, got the results that the mean physical measurements of the children with intellectual and development disabilities fall behind those of the mean values of the non-handicapped children, however, the differences are statistically hardly ever significant.

Similarly, Vámos (19), referring to Laborfalusi's tests, writes that $40 \%$ of the children with intellectual and development disabilities are characterized by a slightly underdeveloped build, lower than the age average body height and weight. In our investigations, we found that among the children with intellectual and development disabilities there were more underdeveloped children, than among the non-handicapped ones. It may also be noted that the non-handicapped girls in most cases were better developed than the boys with intellectual and development disabilities of the same age. It also occurs sometimes that in the same group, the girls were better developed than the boys. However, girls with intellectual and development disabilities were always less developed than the non-handicapped boys.

While the body height shows the age characteristics of the children in the same groups, the body weight and the morphological age in the case of the 8- and 9-year-old boys, do not. However, they are not seen in either group when we consider the two body build indicators (body mass index and the musculoskeletal index) or the two skinfold thickness (triceps and biceps) indicators.

Based on our investigations, it seems it may be confirmed that the children with intellectual and development disabilities are physically also less developed than their nonhandicapped contemporaries of the same sex.

In the motor skills test, they always did worse than the non-handicapped children. The difference in most cases is significant. There was a marked but not significant difference in 
the $20 \mathrm{~m}$ dash between the 8- and 9-year-old boys with different capabilities; in the standing long jump, also between the 9-year-old boys as well as between and the 11-year-old boys; in the medicine-ball throw, there was no such occurrence; in the 6 minutes' continuous running there was no difference between the 11-year-old boys; in the obstacle race test there was a significant difference between all the groups; however, in the match test, there was no significant difference between the 8 -year-old girls, the 9 -year-old boys, the 10 -year-old girls and the 11-year-old boys.

Among the children in the same groups, the boys usually achieved better results than the girls, except for the match test, in which the non-handicapped girls performed better than boys in every age group. The girls with intellectual and development disabilities were the weakest in every case. The non-handicapped girls always performed better than the boys with intellectual and development.

In the case of non-handicapped children, the age differences could be better seen while in the case of the children with intellectual and development disabilities the differences were less to be seen.

Based on our investigations, it can be confirmed that the children with intellectual and development disabilities fell behind the non-handicapped children in all the motor skills tests. In accordance with our findings, Vámos (19) also refers to the fact that there are coordination problems also with the gross motor skills. Similarly, Pilák (11) having compared the performance of the children going to majority schools, reports that the children with slighter intellectual and development disabilities performed worse in every test than the nonhandicapped children. However, our findings do not confirm Pilák's hypothesis (11) that the children with intellectual and development disabilities fall behind the non-handicapped children only in test requiring physical strength, while in the tasks requiring speed and stamina, they do not.

According to our results and also the data already published in technical literature, supporting them, it can be confirmed to a great probability that the children with intellectual and development disabilities fall behind the non-handicapped children in most motor skills.

\section{REFERENCES}

1. Broadhead GD, Church GE: Influence of test selection on physical education placement of mentally retarded children. Adapted Physical Activity Quarterly 1, 112-117 (1984)

2. Buday J, Kaposi I (1988): Body proportions in some chromosomal disorders. (In Hungarian: Értelmi fogyatékos gyermekek testi fejlődése.) Humanbiol, Budapest. 18. 35-39. In MAGYE bulletin: Body Development of Mentally Retarded Children. (In Hungarian: Értelmi fogyatékos gyermekek testi fejlődése. MAGYE kiadvány.) Budapest (2007)

3. Buday J (2006): The Homok Longitudinal Growth Study. (In Hungarian: A homoki longitudinális növekedésvizsgálat.) Budapest.

4. Cole TJ, Bellizzi MC, Flegal KM, Dietz WH: Establishing a standard definition for child overweight and obesity worldwide: international survey. Br. Med. J 320, 1-6 (2000)

5. Enkoyan, G: Adolphe Quetelet (1796-1874): The average man and indices of obesity. Nephrology Dialysis Transplantation, 23 (1) 47-51, (2008)

6. Györi P: Development of condition ability of kindergarten children in experimental and control group. (In Hungarian: Óvodások kondicionális képességének fejlődése kísérleti és kontroll csoportokban.) In: Győri P. (szerk) Óvodások szomatikus nevelése. VEAB Veszprém, pp. 108-130. (1988)

7. Farmosi I, Gaál S (2007): Body- and moving development of kindergarten- and elementary school children. (In Hungarian: Óvodások és kisiskolások testi és mozgásfejlődése.) Dialóg Campus Kiadó, Budapest - Pécs 
8. Leibinger É (2001): Physical education of children with learning disabilities and intellectually impaired. (In Hungarian: A tanulásban és értelmileg akadályozott gyermekek testi nevelése.) Thesis, Budapest

9. Mészáros Zs, Kiss K, Szmodis MB, Zsidegh M, Mavroudes M, Mészáros J: Effects of attending elevated level school physical education in 7 to 11-year-old boys. Acta Physiol. Hung. 96(3), 349-357 (2009)

10. Ozbic M, Filipcic T: Complex imitation of gestures in school-aged children with learning difficulties. Kinesiology 42, 44-55 (2010)

11. Pilák N (2008): Study for motor ability with method of Hungarofit. (In Hungarian: A motoros képességek vizsgálata a Hungarofit módszer segítségével.) Thesis, Budapest

12. Rio L, Pastena N, D’anna C, Gomez Paloma F: Motor Literacy Project as Ideal Setting for Tests Administration in SEN Identification. Procedia-Social and Behavioral Sciences 106, 1857-1865 (2013)

13. Suchomel A: Somatic parameters of children with low and high levels of motor performance. Kinesiology 37(2), 1955-203 (2005)

14. Sziva Á, Mészáros Zs, Kiss K, Mavroudes M, Ng N, Mészáros J: Longitudional differences in running endurance and BODY MASS INDEX - a 25-year comparison. Acta Physiol. Hung. 96 (3), 359-368 (2009)

15. Szmodis M, Bosnyák E, Cselik B, Protzner A, Trájer E, Ács P, Tóth M, Szőts G (2014) Youth-Health-Sport. Comprehensive background study for the effect of sport in primary-, secondary school children and students. (In Hungarian: Ifjúság-egészség-sport. A sportolás hatásának átfogó háttérvizsgálata általános és középiskolások, illetve egyetemisták körében.) Magyar Sporttudományi Füzetek-XI. Magyar Sporttudományi Társaság. Budapest

16. Tóth L: Development of motor ability in the age of adolescence. (In Hungarian: A motoros képességek fejlődése serdülőkorban.) Kalokagathia, 34(1-2) 223-235 (2006)

17. Tóth G (1993): Morphological study of psychiatrian diseased and olygophren attended persons. (In Hungarian: Psychiatriai betegek és oligophren gondozottak testalkati vizsgálata.) Anthrop. Közl. 35. 189-196. In MAGYE bulletin: Body Development of Mentally Retarded Children (In Hungarian: Értelmi fogyatékos gyermekek testi fejlődése. MAGYE kiadvány.) Budapest (2007)

18. Tóth GA, Eiben OG: Secular changes of body measurements in Hungary. Humanbiologia Budapestiensis, 28, 7-72 (2004)

19. Vámos A (2007): Comparative study of motor ability in the first and second classes of normal and variant curriculum primary school. (In Hungarian: A motoros képességek összehasonlító vizsgálata a normál általános iskola és az EÁI 1. és 2. osztályában.) Thesis, Budapest

20. World Medical Association (1996): Ethical principles for medical research involving human subjects. WMA General Assembly, Somerset West, RSA.

21. Zsakai A, Bodzsar EB: The 2nd Hungarian National Growth Study (2003-2006): Annals of Human Biology 39(6), 516-525 (2012) 